\section{Westward Extension of the Ranikot Sea}

IN a previous letter ${ }^{1}$ I showed that the Ranikot (Palæocene) Sea of India must have extended over the whole length of the Himalayas, from eastern Tibet to Waziristan. More recently, some interesting fresh evidence has been found regarding the extent of the Ranikot Sea; for Mr. A. G. Davis, who is working for the Anglo-Iranian Oil Company, informed me that he had found Ranikot fossils in collections made by Dr. J. V. Harrison of that Company from a section near Shamshir-i-Quli (lat. $33^{\circ} 30^{\prime} \mathrm{N}$. ; long. $47^{\circ} 10^{\prime} \mathrm{E}$.) on the western borders of Persia.

These collections $\mathrm{Mr}$. Davis has since shown to me, and I have been able to confirm his opinion, identifying the following species as present: Nummulites nuttalli Davies, $N$. thalicus Davies, Operculinoides ef. sindensis Davies, Miscellanea stampi Davies, M. miscella D'arch. and Haime, Sakesaria cf. cotteri Davies and Alveolina globosa Leymerie. The thickness of Upper Ranikot beds at Shamshir-iQuli is at least 500 feet; and the succeeding less fossiliferous beds, with forms which I referred to Alveolina lepidula Schwager, A. cf. oblonga D'Orbigny and Orbitolites ef. complanatus Lamarck, would seem to be of Laki age. Although true Ranikot fossils have not yet been found in any other collections received by Mr. Davis, the existence of the Ranikot at Shamshir-i-Quli is unquestionable.

The occurrence is worth recording, since Ranikot beds have never before been certainly located much farther west than long. $68^{\circ} \mathrm{E}$. Taken in conjunction with my discovery ${ }^{2}$ last year of an abundant Upper Ranikot fauna in Sir Henry Hayden's collections from Kampa Dzong, due north of Calcutta, this last discovery shows that the Upper Ranikot Sea extended in an east-to-west direction from the vicinity of Lhasa to that of Bagdad.

I am indebted, for permission to publish these facts, to the courtesy of the Anglo-Iranian Oil Company.

\section{M. Davnes.}

\section{Garscube Terrace,} Edinburgh, 12. Dec. 24 .

1 "Extent of the Ranikot Sea", NArURE, 139, 414-415 (1937). 2 "Eocene Beds of the Punjab Salt Range", Pal. Indica (N.S.), 24 Mem. 1, Appendix, 68-71 (1937).

\section{Chemical Structure of Corticosterone}

THE adrenal gland produces a hormone which is essential to life. During the last two years, several workers have succeeded in isolating, from purified preparations of the cortical hormone, a number of crystalline compounds. Among these substances corticosterone and dehydro-corticosterone possess the greatest biological activity. The structures (I) and (II) were proposed for corticosterone and its dehydro derivative ${ }^{1,2}$. These formulæ were not definitely proved, but were chiefly based on the assumption that corticosterone might possess a constitution similar to some of the above-mentioned compounds, which have been isolated from the adrenal gland and which have been found to contain one more atom of oxygen in their molecules. These substances, which can be designated as the $\mathrm{C}_{21}-\mathrm{O}_{5}$-group, contain the sterol ring-system since they can be converted into the hydrocarbon androstane $e^{3}$. The suggestion that corticosterone contains the same ring-system has so far not been supported by any experimental evidence.<smiles>CC12CCC(=O)C=C1CCC1C2C(O)CC2(C)C(C(=O)CO)CCC12</smiles>

(I)<smiles>CC12CC(=O)C3C4CCC(=O)C=C4CCC3C1CCC2C(=O)CO</smiles>

(II)<smiles>CCCC1CCC2C3CCC4CCCCC4C3CCC12C</smiles>

(III)

Allo-pregnane

By means of a series of reactions, the details of which will be published in the Helv. chim. Acta, corticosterone can be transformed into the hydro. carbon allo-pregnane (III) (m.p. $84^{\circ},[\alpha]^{21}=+12 \cdot 7^{\circ}$ in chloroform). The same hydrocarbon was also obtained by a Clemmensen reduction of allo-pregnane. dione-3.204. This evidence appears, therefore, to prove the presence of a steroid structure in corticosterone.

Marguerite Steiger.

Laboratorium für organ. Chemie,

\section{T. REICHSTEIN}

Eidg. Techn. Hochschule, Zurich.

${ }^{1}$ Kendall, E. C., Mason, H. L., Hoehn, W. M., McKenzie, B. F., Proc. Staff Meet. Mayo Clinic, 12, 136 (1937). J. Biol. Chem., 120 719 (1937).

' Reichstein, T., Helv. chim. Acta, 20, 953 (1937).

- Reichstein, T. Helv, chim. Acta, 19, 979 (1936); 20, 978 (1937). Steiger, M., and Reichstein, T., Helv. chim. Acta, 20, 817 (1937).

- Butenandt, A., und Westphal, U., Ber. deut. chem. Ges., 67, 1440 (1934). Butenandt, A., Westphal, U., und Hohlweg, W., $Z$. physiol. Chem., 227, 84 (1934).

\section{Treatment with Ascorbic Acid of the Plasma of a} Fowl affected by Erythroblastosis

In the course of researches aiming at investigating the nature of the virus of aviary erythroblastosis, the following observations were made.

By adding to the plasma (plus sodium oxalate) of a fowl seriously affected by erythroblastosis (O. G. strain which we owe to the kindness of Prof. Oberling) ascorbic acid in determinate proportions, a turbidness was noticed in the plasma itself which, after having been kept in the ice-chest for some hours, became transformed into a precipitate. $0.1 \mathrm{gm}$. of ascorbic acid was dissolved in an 8 per cent sodium chloride solution. This solution was added to the plasma as soon as the ascorbic acid was dissolved. The final concentration of ascorbic acid in respect to the plasma was 1 : 150 . 